\title{
Vapaan sivistystyön olemus ja päämäärät
}

Tampereen yliopiston täydennyskoulutuskeskus järjesti yhteistyössä Tampereen yliopiston aikuis- ja nuorisokasvatuksen laitoksen ja Aikuiskasvatuksen Tutkimusseuran kanssa 17. - 18.5.82 seminaarin aiheesta "Vapaan sivistystyön olemus ja päämäärät'. Avauspuheenvuorossaan Tutkimusseuran esimies totesi, että seminaari voidaan nähdä jatkona vuosina 1967 ja 1968 pidetyille aikuiskasvatuksen tavoitteita ja arvoperusteita käsitelleille seminaareille, joiden aineistosta kerättiin aikoinaan Erkki Karjalaisen toimesta kirja "Vapaan sivistystyön tavoitteet" (1970). Koska olemus ja päämääräkysymykset ovat kuitenkin tavallaan kaikkia alalla työskenteleviä koskettava "iäisyyskysymys", niin tällainen seminaari oli nähty tarkoituksenmukaiseksi jälleen järjestää. Seminaarin järjestäminen oli hänen mukaansa tärkeää myös siksi, että Aikuiskoulutuksen kehittämisorganisaation työskentelyn yhteydessä on jouduttu jälleen pohtimaan ja palaamaan tällaisiin alan peruskysymyksiin. On myös huomattava, että runsaan kymmenen vuoden aikana alalle on tullut paljon uusia työntekijöitä, jotka eivät omakohtaisesti ole näitä kysymyksiä juurikaan pohtineet.

Kokouksen ensimmäisen alustuksen piti prof. Urpo Harva aiheesta "Vapaan sivistystyön olemus". (Koska hänen alustuksensa on julkaistu kokonaisuudessaan toisaalla tässä lehdessä, niin sitä ei esitellä tässä sen enempää.) Hänen jälkeensä puhui prof. Kosti Huuhka "Vapaan sivistystyön päämääristä'. Hänen mukaansa vapaassa sivistyössä eletään ' pelkojen ja epäilyjen aikaa", Hän näki vapaan sivistystyön tunnus- piirteinä seuraavat kolme seikkaa: 1) se on vapaaehtoisesti harjoitettua toimintaa, 2) siihen osallistuminen on vapaaehtoista ja 3) sillä on jokin arvopohjainen koulujärjestelmän ulkopuolinen tarkoitus. Vapaan sivistystyön tarkoituskohdat on määritelty hänen mukaansa laeissa ja asetuksissa vain suhteellisen yleisellä tasolla. Niissä ilmenee vain minkälaisessa henkisessä ilmapiirissä toiminta tapahtuu ja ketkä ovat toiminnan kohteena. Hän piti huolestuttavana sitä, että tällä hetkellä kansansivistystyön arvot ja ideologiat tulevat ulkoapäin, eikä kansansivistäjillä ole niihin juurikaan sanottavaa. Tällöin nämä sivistystyön ulkopuoliset - useinkin varsin kapeaalaisiin ja ahtaisiin tavoitteisiin tähtäävät - organisaatiot rajoittavat ja ehkäisevät sivistystyön perimmäistä päämäärää, kokonaispersoonallisuuden kehittämistä.

Kansanopistojen edustaja, rehtori Paavo Suvanto totesi kommenttipuheenvuorossaan, ettei hän hyväksy kansanopistojen sijoittamista yhteiskunnan koulutusjärjestelmän osaksi. Vapaan sivistystyön organisaatioista kansanopistot sopivat hänen mielestään kaikkein huonoimmin koulutusjärjestelmän osaksi, koska kansanopistoilla on seuraavat kolme tunnusomaista piirrettä: 1) ne ovat sisäoppilaitoksia, 2) niissä vallitsee hyvin pitkälle ideologinen ja pedagoginen vapaus ja 3) niillä on omavastuinen tehtävänhaku.

Sivistysjärjestöjen edustaja, pääsihteeri Jussi Pikkusaari totesi, etteivät järjestöt yksin riitä yhteydenpitokanavaksi laajoihin kansalaispiireihin, koska ne tavoittavat järjestöistäkin lähinnä vain erilaiset luottamushenkilöt, ja muut kansalaiset jäävät lähes kokonaan niiden ulkopuolelle. Tästä syystä hän esitti sivistysjärjestöjen työn kehittämistä seuraavien vaiheiden kautta: 1) lähtökohtana tulisi olla "vapaat kansalaiset", 2) seuraavaksi olisi huomioitava vapaat kansanliikkeet, 3) primaarijärjestöt sekä 4) muut sivistystyöinstituutiot. Siitä missä määrin edellä mainitut tahot kyetään todella ottamaan kehittämisessä huomioon, riippuu paljolti sivistysjärjestöjen asema tulevaisuuden yhteiskunnassa.

Puhuessaan vapaudesta ja sidonnaisuudesta vapaassa sivistystyössä lehtori Veikko Veilahti korosti sitä, että vapaa sivistystyö lähtee ihmisen itsesäätöisyyden perusajatuksesta. Koulumaisen opetuksen osuuden hän arveli viime vuosina lisääntyneen. Vapaa sivistystyökin näyttää muuttuvan yhä enemmän "'kunnalliseksi aikuiskoulutukseksi'. Tätä Veilahti piti huolestuttavana piirteenä, koska tämä kehitys saattaa johtaa vapaan sivistystyön pedagogisen vapauden katoamiseen. Yhteistyön tehostaminen kunnallisella tasolla on toki tärkeää, mutta siihen on löydettävä sellainen menettelytapa, ettei se vaaranna vapaan sivistystyön perinteistä vapautta, totesi Veilahti.

Olemus- ja päämääräkysymysten teoreettisen pohdiskelun lisäksi seminaarissa tarkasteltiin vapaan sivistystyön asemaa nyky-yhteiskunnassa myös käytännölliseltä kannalta. Niinpä osastopäällikkö $\mathbf{M}$. E. Virtanen tarkasteli esityksessään vapaan sivistystyön suhdetta koululaitokseen ja kulttuurineuvos Risto Kivelä kulttuuritoimintalakiin. Edellistä esitystä kommentoi koulutoimenjohtaja Alpo Reinivaara ja jălkimmäistä kult- 
tuuritoimenjohtaja Timo Kukkasmäki. Alustus- ja kommenttipuheenvuorot, virittivät vilkkaan keskustelun, josta ilmeni osanottajien huolestuneisuus vapaan sivistystyön perinteisestä vapaudesta ja autonomiasta. Hälyyttä- vimpänä tilanne nähtiin kansalaisopistojen kohdalla, koska niiden liittämistä tiiviimmin kunnan kouluhallinnon piiriin on jo suunniteltu. Tällaisen ratkaisun pelättiin johtavan opistojen autonomian ja perinteisen sivistysajattelun näivettymiseen. - Seminaariin osallistui noin 50 aikuiskasvattajaa vapaan sivistystyön eri tehtäväaloilta.

Jukka Tuomisto 